\title{
非言語ヒューマンインタフェースのためのコミュニケー ション動作の計測，分析”
}

\section{渡邊昭二**, 中村和男}

\begin{abstract}
In daily personal communication, nonverbal expression plays an important role. It is crucial to build nonverbal human interface systems for realizing a friendly information environment. In the future, computer will understand real human motions, and create human mimetic motions in CG, ie., Virtual mannequin, for interactive conversations. A structural model for understanding nonverbal expression in communication was proposed. This model is composed of a functional combination of real motions, measuring data of the motions, physical motion features, linguistic motion features and feelings of player's motions. Focusing on head motions in human communication, experiments of motion capturing were conducted in a laboratory, and motion feature indices were extracted from the sequential motion capture data. The video images of human body motions were used for questionnaire surveys. From the results of questionnaire surveys, the linguistic motion features and the feelings of player's motions were extracted. Relationships among the motion feature indices, the linguistic motion features and the feelings of player's motions were analyzed by multivariate analyses. From all of the obtained results, validity of the mathematical approach was verified according to the proposed structure model and the analyzing methods. Then this result shows the potential of developing nonverbal human interface technology by this framework.
\end{abstract}

非言語ヒューマンインタフェースを構築することは，人に優しい情報環境を実現する上で重要であ る. 将来的には人間の動作を理解し, CG の動作生成などによってインタラクティブに対応できる非 言語ヒューマンインタフェースの構築を目指す. 本研究では, 非言語表現を, 実際の身体動作, 動作 の計測データ, 物理的動作特徵, 言語的動作特徵, 人物の感情・意図の 5 段階の理解構造モデルとし て捉えることを提案した. 本論文では頭部の動きがかかわるコミュニケーション動作に着目し, 動作 計測実験を経て身体動作の時系列計測デー夕を収集し，そこから物理的動作特徵の指標を構築するこ とで, 質問紙調査によって抽出された人物の言語的動作特徵と感情・意図の関連構造を多変量解析手 法によって分析した. 得られた分析結果等から, 構造モデル, 分析方法については, 数理的アプロー チの有効性が確認され, 非言語ヒューマンインタフェース技術への展開の可能性が示唆された. (キーワード : 非言語表現, ヒューマンインタフェース, 三次元動作解析, 多変量解析手法)

* 受付： 2002 年 1 月 7 日 受理： 2002 年 6 月 3 日

** 長岡技術科学大学大学院 工学研究科 Graduate School of Engineering, Nagaoka University of Technology

*** 長岡技術科学大学 経営情報系

Department of Management and Information Systems Science, Nagaoka University of Technology

\section{1. はじめに}

ヒューマンインタフェースの進展は目覚ましく, 現 在日常的に使用されているマウス, キーボード, GUI などのヒューマンインタフェースから次世代のヒュー マンインタフェースへの推移が期待されている.我々 が日常生活で行う対人コミュニケーションにおいて言 語的な表現のほかに，非言語的な表現の占める割合は 
大きい. M. F. ヴァーガス ${ }^{1)}$ は「2者間の対話では, ことばによって伝えられるメッセージは，全体の $35 \%$ にずず, 残りの $65 \%$ は話しぶり, 動作, ジェ スチャー，相手との間のとり方など，ことば以外の手 段によって伝えられる」としている.P. エックマ ン2,3) は身体動作を表象, 例示子, 情感表示, 調整子, 適応子の 5 種類に分類している.このなかで表象, 例 示子は意図的に表出されることが多いが，情感表示， 調整子, 適応子はたいていの場合メッセージ伝達の意 図なしに表出されるという特徴を持つ. 本研究ではこ れら情感表示, 調整子, 適応子を自然なしぐさとして 捉えることにした. コミュニケーション時に表出され る動作のなかで, 表情と並んで重要とみられるしぐさ に注目すると現状のヒューマンインタフェースへのア プローチにおいては, 意図的な動作やサインランゲー ジを活用するものは多いが，自然なしぐさを積極的に 活用するものはまだ少ない ${ }^{4,5)}$.ここでは自然なしぐ さを積極的に活用した非言語ヒューマンインタフェー スを構築することは人に優しい情報環境を実現してい く上で意義深いことと考え, 将来的にコンピュー夕に よって人間の動作が読み取られ，CGによって仮想動 作が生成されるなどインタラクティブに対応できる非 言語ヒューマンインタフェースの構築を目指す。自然 なしぐさを積極的に活用した非言語ヒューマンインタ フェースは, 教育, 福祉, 娛楽といった分野のインタ フェースシステムの開発に資すると考えられる。本研 究では自然なしぐさに注目して, 非言語表現の理解構 造モデルを提案し, 動作計測, 分析方法の枠組みを示 し，それに沿った具体的計測分析の可能性を検討する ことを目的とした.

\section{2. 非言語表現の理解構造モデルと分析 方法の枠組み}

本研究では自然なしぐさを実際の身体動作, 動作の 計測デー夕, 物理的動作特徵（例：眉間点の上下方向 の速度の最大値), 言語的動作特徵（例：耳を傾ける, 首をかしげる), 人物の感情・意図（例：興味, 集中, 思考）の 5 段階の情報状態の間の変換メカニズムとし て捉えることにし, 図 1 に非言語表現の理解構造モデ ルとして示した。従来の研究例6によく見られる物理 的動作特徴から人物の感情・意図を直接認識するので はなく, マクロ的な動作特徵としての言語的動作特徵 に変換することは, 内部構造がブラックボックス化せ ず人間に理解しやすい構造といえる。 また言語的動作 特徵としての要素的な動作パターンを明らかにし, そ れらを中間階層として導入することは非言語インタフ

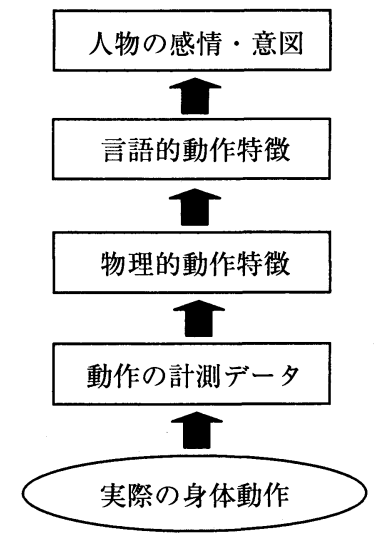

図 1 非言語表現の理解構造モデル

Fig. 1 A structural model for understanding nonverbal expressions in communication.

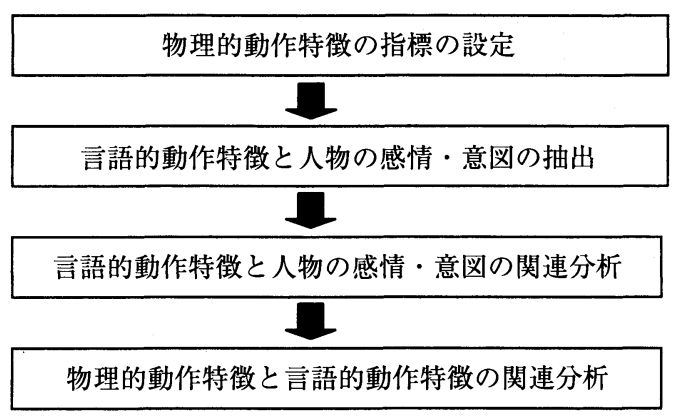

図 2 分析方法の枠組み

Fig. 2 Outline of the analysis process.

エースを構築する上でシステム構造の単純化に役立つ と考えられる. 動作計測, 分析をこの提案モデルに従 って行った. 図 2 に分析方法の枠組みを示す. 動作の 計測デー夕から多数の物理的動作特徵が算出され, そ の多数の物理的動作特徵から少数でかつ本質的な指標 が抽出される. 実際の身体動作から, 言語的動作特徵 と人物の感情・意図がそれぞれ抽出される. 人物の感 情・意図は言語的動作特徵によって判別され，言語的 動作特徵は少数でかつ本質的な物理的動作特徴の指標 によって判別される。

\section{3. 実験方法}

実験室下での動作計測をできるだけ実生活場面で表 出される動作モードに近づけるために, 被験者が演技 しやすいよう動作パターンが比較的単純な動作部位で ある頭部の動作に注目することにした．設計のための 人体計測マニュアル7) を参照して, 図 3 に示す被験者 の頭部の各測定点（ $\mathrm{g}$ ：眉間点，leu, reu：側頭点（左 


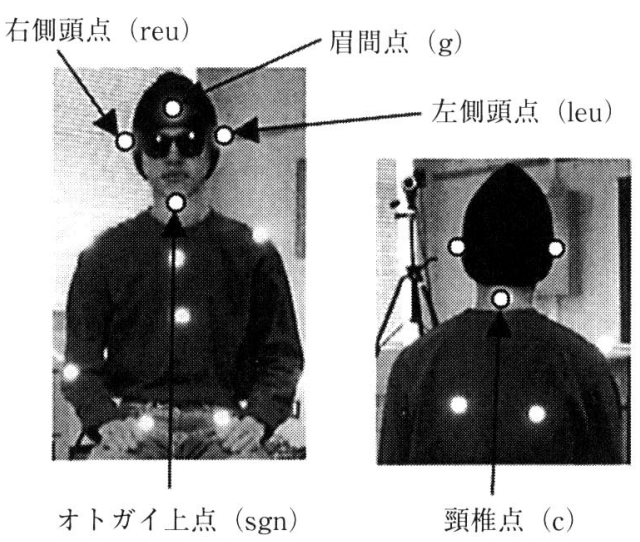

図 3 光学マーカの貼り付け位置

Fig. 3 The marking positions.

右 2 点), sgn：オトガイ上点, c : 頸椎点）に動作計 測用の光学マーカを貼り付けた. そして三次元動作解 析装置（Vicon 370 Oxford Metrics 社製）によって 被験者に貼り付けた光学マーカの時系列的な位置デー 夕（モーションキャプチャデータ）の測定を行った. また実験風景の映像記録にはデジタルビデオカメラ （SONY-DCR-TRV 20）を使用した．動作計測実験 を，実験 I と実験 II 二つの異なるパターンで行っ た。以下に実験の概要を示す。

\section{3-1． 実験 I：人工的な動作の計測実験}

いくつかのジャンルにあらかじめ分類された動作を 被験者が演技することで，人工的であるが系統化され た動作のモーションキャプチャデータを取得し，そこ から動作パターンを判別するための物理的動作特徵の 指標を抽出することを目的とした。

\section{(1) 被験者}

被験者は成人男性 2 名, 成人女性 3 名の計 5 名であ った.

\section{（2）演技内容}

動作の内容, 方向, 大きさ, 時間, 速さについて具 体的な文章で記述されたインストラクションを作成寸 る（例：椅子に座って正面を向いた姿勢から，できる だけ大きく素早く左を向き，5秒後正面を向く). 作 成されたインストラクションに沿った動作を被験者に 演技してもらい，動作計測を行った。

(3) 取得データ

136 パターン（動作パターン）×5人（被験者数）の モーションキャプチャデータが得られた.

\section{3-2. 実験 II：自然な動作の計測・理解実験}

日常生活で表出される動作に近くなるよう工夫した
上で，被験者の感情・意図を反映させた動作のモーシ ヨンキャプチャデータとビデオイメージを取得し，そ こから言語的動作特徵と, 人物の感情・意図の特徵を 抽出することを目的とする.

\section{(1) 被験者}

被験者は 20 代の男性 1 名であった.

\section{(2) 演技内容}

しぐさの英語表現辞典8) をもとに自然なしぐさのイ ンストラクションを作成した（例：首をかしげる（問 いかけの様子)．インストラクションに記述されてい る動作はメッセージの伝達の意図なしに表出されるも のを選定しており，その内容は実験 I と比較して，具 体的よりむしろ慣用的な表現がほとんどである．与え られた動作のインストラクションをもとに被験者はそ の動作を思い浮かべ，インストラクションに記述され ている状況で表出されると思われる動作を演技し，そ のときの動作計測を行った。

(3) 取得データ

32 パターン（動作パターン）のモーションキャプ チャデータと 39 パターン（動作パターン）のビデオ イメージが得られた。

\section{(4) 質問紙調査}

記録された 39 パターンのビデオイメージに対して， 観察者としての本学学生 33 名による質問紙調査を行 った。観察者には，被験者の映っているビデオイメー ジを見せ，その動作をよく観察してもらい，質問紙に その特徴を自由記述式に記入してもらった，質問の項 目は，(a) 言語的動作特徵（例：頭を下げる，横を向 <，等)，(b)人物の感情・意図（例：納得, 興味, 等),であった。

\section{4. 実験結果}

\section{4-1. 物理的動作特徵の指標の設定}

実験 I の人工的な動作の計測実験によって計測され たモーションキャプチャデータを時系列的なテキスト データに変換し，さらに図 4 に示す人体を基準とした 座標値（X 軸：左右方向， $\mathrm{Y}$ 軸：前後方向， $\mathrm{Z}$ 軸：上 下方向）として出力した。

頭部の移動運動から各座標点の基準点からの偏差, 速度, 加速度が算出された。また頭部の回転運動か ら，角度，角速度，角加速度が算出された。これらの 状態量をもとに，最小值，最大值，総和の值などを算 出することで，216の物理的動作特徵の指標が設定さ れた。

次に 216 の物理的動作特徴の指標から少数で本質的 
な指標に代表させるために680（動作パターン：136, 被験者数：5）×216（物理的動作特徵の指標）の行列 デー夕を作成し，主成分を 36 次元にして主成分分析 を行った。そして主成分分析によって得られた因子負 荷量行列（216（物理的動作特徵の指標）×36（主成 分）をもとに 216 の物理的動作特徵に対してワード 法による階層的クラス夕分析を行った ${ }^{8,9)}$. 階層的ク ラスタ分析の結果, 216 の物理的動作特徵の指標はい くつかのグループにまとめられ，それぞれのグループ の指標のなかでデータ分析上先頭にある指標をそのグ ループの代表の指標とした.

次に 680 (動作パターン：136, 被験者数：5）×120
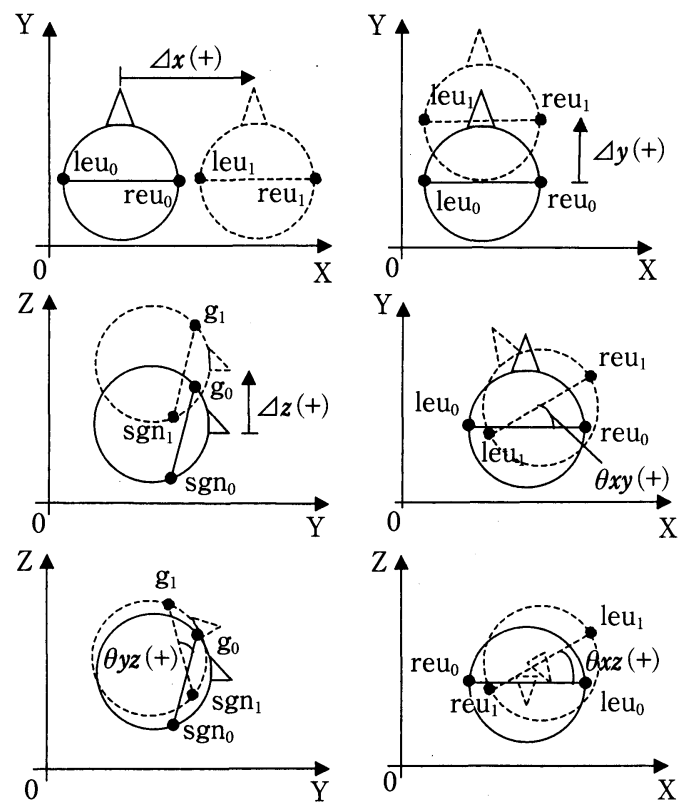

図 4 頭部動作の座標系

Fig. 4 Coordinate of the head motion.

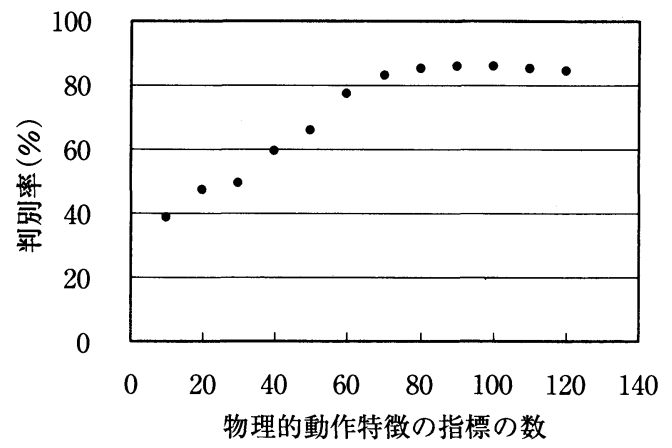

図 5 物理的動作特徴の指標数と判別率の関係

Fig. 5 Discriminant rate corresponding to the number of physical motion features.
(階層的クラス夕分析によって抽出された物理的動作 特徵の指標）の行列デー夕を作成し，120（階層的ク ラスタ分析によって抽出された物理的動作特徵の指 標）のなかから 10～120 の部分的な指標を説明変数に して, 136 種類の群変数としての動作パターンの判別 を線形判別分析で行った. 図 5 に物理的動作特徵の指 標数と判別率の関係を示す.

物理的動作特徵の指標数が 70 のときに判別率が 83\%となった，それ以降は，指標数を增やしても，判 別率は著しく上がることがないため，ここではこの 70 の物理的動作特徵の指標を主要な少数の物理的動 作特徵の指標とした。

\section{4-2． 言語的動作特徵と人物の感情・意図の抽 出}

実験 II について質問回答結果の各記入項目に注目

表 1 抽出された言語的動作特徵のグループ

Tab. 1 Extracted groups of principal linguistic motion features.

\begin{tabular}{|c|c|c|}
\hline $\begin{array}{l}\text { グルー } \\
\text { プ番号 }\end{array}$ & グループ解釈 & $\begin{array}{c}\text { 抽出された } \\
\text { サンプル群の一例 }\end{array}$ \\
\hline $\mathrm{k} 1$ & $\begin{array}{l}\text { 頭部の左右方向の動作 } \\
\text { (動的) }\end{array}$ & 顔を背ける \\
\hline $\mathrm{k} 2$ & $\begin{array}{l}\text { 頭部の左右方向の動作 } \\
\text { (姿勢的) }\end{array}$ & 頭を傾ける \\
\hline k 3 & $\begin{array}{l}\text { 頭部の左右方向の連続 } \\
\text { 的動作（速い） }\end{array}$ & 首を振る \\
\hline k 4 & $\begin{array}{l}\text { 頭部の左右方向の連続 } \\
\text { 的動作（遅い） }\end{array}$ & 首を回す \\
\hline k 5 & $\begin{array}{l}\text { 頭部の斜め下方向の動 } \\
\text { 作（遅的） }\end{array}$ & 首をかしげる \\
\hline k 6 & $\begin{array}{l}\text { 頭部の斜め下方向の動 } \\
\text { 作（速い） }\end{array}$ & 頭を斜めに下げる \\
\hline k 7 & $\begin{array}{l}\text { 頭部の下方向の動作 } \\
\text { (動的) }\end{array}$ & 頭を下げる \\
\hline k 8 & $\begin{array}{l}\text { 頭部の下方向の動作 } \\
\text { (姿勢的) }\end{array}$ & 顎を引く \\
\hline k 9 & $\begin{array}{l}\text { 頭部の上下方向の連続 } \\
\text { 的動作 }\end{array}$ & 首が上下に動く \\
\hline $\mathrm{k} 10$ & 上体の伸び動作 & 背筋を伸ばす \\
\hline k 11 & $\begin{array}{l}\text { 頭部の上方向の動作 } \\
\text { (小規模) }\end{array}$ & 頭を上げる \\
\hline k 12 & $\begin{array}{l}\text { 頭部の上方向の動作 } \\
\text { (大規模) }\end{array}$ & 顎を上げる \\
\hline $\mathrm{k} 13$ & 上体の姿勢変化 & 体を傾ける \\
\hline
\end{tabular}


し, 回答数の合計を集計して合計值が 2 以下の項目・ 用語を省いたのち，動作パターンに項目・用語が見ら れた場合 1 を出力することにした。このようなデータ の変換，集約を経て，81（言語的動作特徴の項目・用 語 $) \times 39$ (動作パターン) と 116 （人物の感情・意図 の項目・用語) $\times 39$ (動作パターン) の行列データを 作成した. 次に, 各項目・用語の分類を行うために, 作成された行列デー夕に対して，数量化 3 類分析を行 った。 そして，各項目・用語をグルーピングするため に数量化 3 類分析によって得られたカテゴリウェイト に対してワード法による階層的クラスタ分析を行っ た. (a) 言語的動作特徵は 13 グループ（k 1 k 13）に 分類され, 10 次元までの累積寄与率は 0.61 であっ た. (b) 人物の感情・意図は 16 グループ (e 1 e 16) に分類され, 10 次元までの累積寄与率 0.53 であっ た.表 1 に抽出された言語的動作特徵のグループを示

表 2 抽出された人物の感情・意図のグループ

Tab. 2 Extracted groups of principal feelings for player's motions.

\begin{tabular}{|c|c|}
\hline $\begin{array}{l}\text { グルー } \\
\text { プ番号 }\end{array}$ & 抽出されたサンプル群の一例 \\
\hline e 1 & $\begin{array}{l}\text { 眠気, 落胆, 疲労, 無気力, 失望, 退屈, 倦 } \\
\text { 急, 憂鬱 }\end{array}$ \\
\hline e 2 & 悲観，焦り，心配 \\
\hline e 3 & 絶望, 苦悩 \\
\hline e 4 & $\begin{array}{l}\text { 疑問, 脱力, 困惑, 思考, 不満足, 反発, } \\
\text { 疑惑, 当惑 }\end{array}$ \\
\hline e 5 & 敵意, 不信, 威嚇, 弛緩, 反感, 不満, 弱気 \\
\hline e 6 & $\begin{array}{l}\text { 注意，特になし，嫌悪，集中，悲しみ， } \\
\text { 警戒，思案 }\end{array}$ \\
\hline e 7 & 疑念, 諦め, 悲嘆, 後攸, 虚脱, 忍耐 \\
\hline e 8 & 不快，安心，安堵，意気消沈，動摇 \\
\hline e 9 & $\begin{array}{l}\text { 興味, 関心, 好奇心, 観察, 確認, 発見, } \\
\text { 注目, 無視 }\end{array}$ \\
\hline e 10 & $\begin{array}{l}\text { 緊張, 高慢, 自信, 強気, 気分転換, 決意, } \\
\text { 自慢 }\end{array}$ \\
\hline e 11 & $\begin{array}{l}\text { 挨拶，同意，承諾，了解，納得，肯定， } \\
\text { 理解，同感，賛同 }\end{array}$ \\
\hline e 12 & $\begin{array}{l}\text { 不賛成, 不機嫌, 優越, 軽翤, 自尊, 不安, } \\
\text { 不承知 }\end{array}$ \\
\hline e 13 & 高楊, 沈静 \\
\hline e 14 & 拒否, 無関心, 怒り, 不愉快, 拒絶, 躊躇 \\
\hline e 15 & 否定，混乱 \\
\hline e 16 & 感謝, 反省, 留願, 依頼, 尊敬 \\
\hline
\end{tabular}

す.表 2 に抽出された人物の感情・意図のグループそ 示す.

\section{4-3． 言語的動作特徵と人物の感情・意図の関 連分析}

次に提案モデルに含まれる言語的動作特徵と人物の 感情・意図の関連構造についての評価を行うために, 39 (動作パターン) $\times 13$ (言語的動作特徴のグループ) と 39 (動作パターン) $\times 16$ (人物の感情・意図のグル ープ）の行列データを作成した（各グループが動作パ ターンに該当する場合 1 の值を取る). 39 の動作パ夕 ーンに関して, 13 （言語的動作特徴のグループ）の説 明変数で, 16 (人物の感情・意図のグループ）それぞ れの群変数の判別を数量化 2 類分析で行った．図 6 に 数量化 2 類分析による固有値を示す.

固有值は，0.24 0.64の值であり，平均値は 0.39 であった. 群変数の種類により, 大きく異なる値をと ることから, 人物の感情・意図のグループのなかでも 判別に向き，不向きがあることを示している．図 7 に 数量化 2 類分析によるカテゴリウェイトの一例として グループ e 11 の判別について示す.

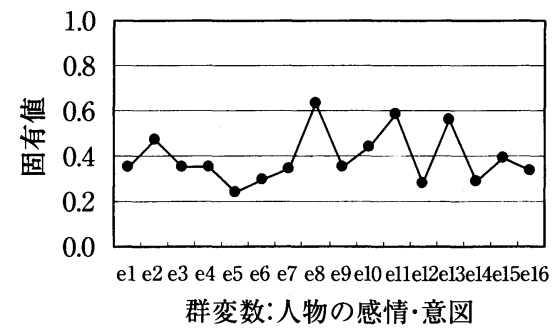

図 6 言語的動作特徴による感情・意図の判別のための数 量化 2 類分析による固有値

Fig. 6 Eigenvalues by quantification method 2 to distinguish feelings of player's motions by linguistic motion features.

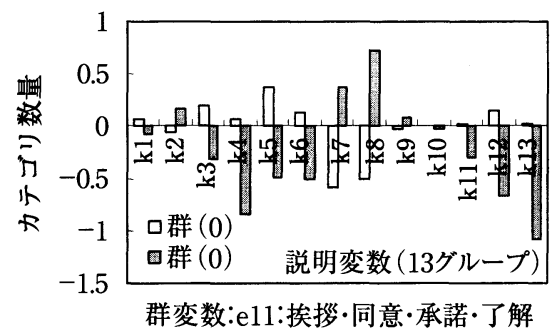

図 7 言語的動作特徴による感情・意図の判別のための数 量化 2 類分析によるカテゴリ数量の一例

Fig. 7 An example of category scores by quantification method 2 to distinguish feelings of player's motions by linguistic motion features. 
この例では, 固有値は 0.58 , 判別率は $85 \%$ となっ た.グループ $\mathrm{e} 11$ すなわち挨拶，同意，承諾，了解 といった人物の感情・意図グループに対しては, $\mathrm{k} 7$ の頭部の下方向の動作（動的）や，k 8 の頭部の下方 向の動作（姿勢的）といったグループはプラス要因 で, k 4 の頭部の左右方向の連続的動作（遅い）や $\mathrm{k} 12$ の頭部の上方向の動作（大規模）といったグル ープはマイナス要因であると解釈できる。ここでは, プラス要因が強いほどグループ e 11 と判別されるこ とを意味している。なお e $1 \sim \mathrm{e} 16$ の分析結果から， 判別率の平均值は $75 \%$ であった。

\section{4-4. 物理的動作特徵と言語的動作特徵の関連 分析}

39 (動作パターン) ×70（主要な少数の物理的動作 特徴の指標）と 39 (動作パターン) ×13（言語的動作 特徵のグループ）の行列データを作成し，39 の動作 パターンに関して，70（主要な少数の物理的動作特徵 の指標）の説明変数で, 13 （言語的動作特徵のグルー プ）それぞれの群変数の判別を線形判別分析で行っ た. 図 8 は, 線形判別分析によって得られた各群変数 に対する判別率である. 言語的動作特徵のグループの 判別率の平均值は，98\%で, 人物の感情・意図のグル ープの判別率の平均値は $97 \%$ であった.

図 9 は, 線形判別係数の一例で, 言語的動作特徴の $\mathrm{k} 1$ グループを線形判別関数で判別したときに，影響 度の高い物理的動作特徴の指標を示したものである. 図 10 は, 偏 $F$ 值の一例で, 言語的動作特徵の $\mathrm{k} 1$ グ ループを線形判別関数で判別したときに，各変数が式 のなかでどれだけ有意性を持っているか示したもので ある. 表 3 にそれらの物理的動作特徵の指標の記号と その意味を示す.

図 9 と図 10 から, 線形判別係数の絶対值が高く,

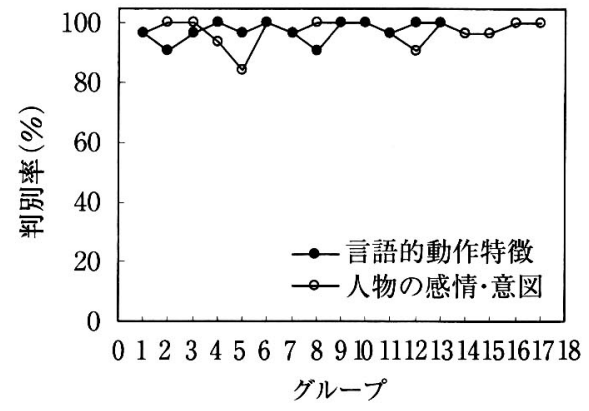

図 8 言語的動作特徵および人物の感情・意図に対する判 別率の関係

Fig. 8 Discriminant rate concerning linguistic motion features and feelings of player's motions.
かつ偏 $F$ 值も高い変数が言語的動作特徵の $\mathrm{k} 1$ グル ープ, すなわち頭部の左右方向の動作（動的）のグル ープを判別する上で重要な変数となるので, 眉間点の 右方向の速度の総和や眉間点の基準点からの左方向の 偏差の最小值といった指標がプラス要因の重要な変数 で，眉間点の基準点からの左方向の偏差の総和や眉間 点の前方向の速度の最大值といった指標がマイナス要 因の重要な変数であるといえる，プラス要因の変数が 現れているほど，グループ $\mathrm{k} 1$ と判別されることを意 味する．指標からは，判別された動作のグループは， 動作の継続時間よりはむしろ動作の大きさといった要 素を反映していて，上下方向などの動作ではなく，左 右方向の動作を表現していると解积することができ る. 被判別グループが変化した場合, 線形判別係数と 偏 $F$ 值も変化するため, 判別されるグループによっ て判別に影響度の高い変数は異なる.

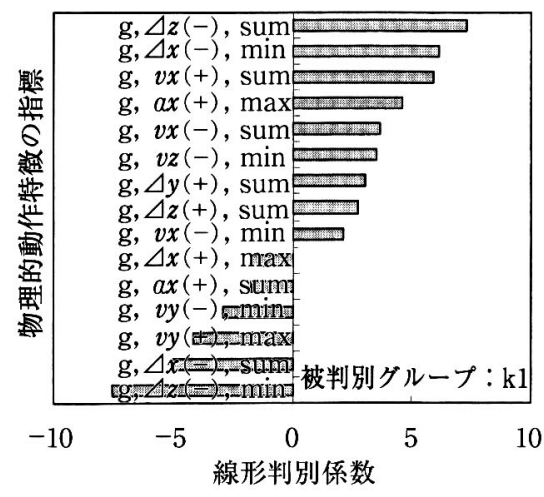

図 9 線形判別係数の一例

Fig.9 An example of linear discriminant coefficients.

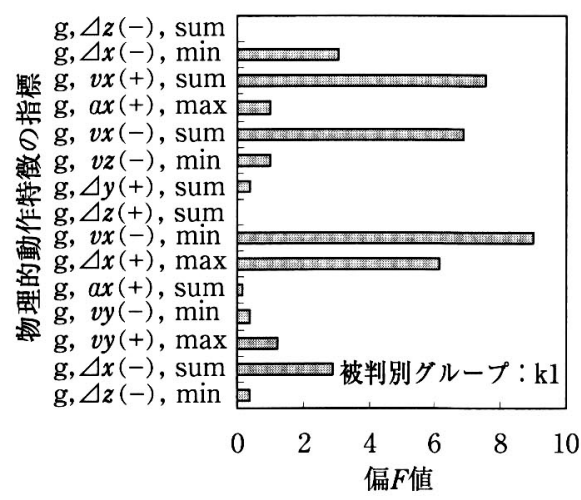

図 10 偏 $F$ 值の一例

Fig. 10 An example of partial $F$-values. 
表 3 図 9 と図 10 に表される物理的動作特徵の指標

Tab. 3 Physical motion feature indices shown in the Fig. 9 and the Fig. 10.

\begin{tabular}{|c|c|}
\hline 記 号 & 記号の意味 \\
\hline $\mathrm{g}, \Delta z(-)$, sum & $\begin{array}{l}\text { 眉間点, 基準点からの下方向の偏差, } \\
\text { 総和 }\end{array}$ \\
\hline $\mathrm{g}, \Delta x(-), \min$ & $\begin{array}{l}\text { 眉間点, 基準点からの左方向の偏差, } \\
\text { 最小値 }\end{array}$ \\
\hline $\mathrm{g}, v x(+)$, sum & 眉間点, 右方向の速度, 総和 \\
\hline $\mathrm{g}, \alpha x(+), \max$ & 眉間点, 右方向の加速度, 最大值 \\
\hline $\mathrm{g}, v x(-)$, sum & 眉間点, 左方向の速度, 総和 \\
\hline $\mathrm{g}, v z(-), \min$ & 眉間点, 下方向の速度, 最小值 \\
\hline $\mathrm{g}, \Delta y(+)$, sum & $\begin{array}{l}\text { 眉間点, 基準点からの前方向の偏差, } \\
\text { 総和 }\end{array}$ \\
\hline $\mathrm{g}, \Delta z(+)$, sum & $\begin{array}{l}\text { 眉間点, 基準点からの上方向の偏差, } \\
\text { 総和 }\end{array}$ \\
\hline $\mathrm{g}, v x(-), \min$ & 眉間点, 左方向の速度, 最小值 \\
\hline $\mathrm{g}, \Delta x(+), \max$ & $\begin{array}{l}\text { 眉間点, 右方向の基準点からの偏差, } \\
\text { 最小値 }\end{array}$ \\
\hline $\mathrm{g}, \alpha x(+)$, sum & 眉間点, 右方向の加速度, 総和 \\
\hline $\mathrm{g}, v y(-), \min$ & 眉間点, 後方向の速度, 最小值 \\
\hline $\mathrm{g}, v y(+), \max$ & 眉間点，前方向の速度，最小值 \\
\hline $\mathrm{g}, \Delta x(-)$, sum & $\begin{array}{l}\text { 眉間点, 基準点からの左方向の偏差, } \\
\text { 総和 }\end{array}$ \\
\hline $\mathrm{g}, \Delta z(-), \min$ & $\begin{array}{l}\text { 眉間点, 基準点からの下方向の偏差, } \\
\text { 最小值 }\end{array}$ \\
\hline
\end{tabular}

\section{4-5. 実験者の意図と観察者の理解の一致度の 評価}

被験者が演じた動作に対して観察者が理解した内容 （観察者の理解）と 39 の演技動作のインストラクショ ン（実験者の意図）にギャップがある可能性があるた め, 次の評価を行った。

(1) 動作に関するビデオ映像を視聴者 33 名に視聴 してもらいその動作の印象についての質問紙（39 動 作パターン×33 視聴者）に記述されている動作の語 句を言語的動作特徵 13 グループの語句に置換（例： うなずく $\rightarrow$ 頭部の上下方向の動作 (動的)）し，各動 作パターンに対する観察者の印象の言語的動作特徴 13 グループへの該当度を求めファジィ集合 $A_{V}$ のメ ンバーシップ度とみなす.

(2) 39 の演技動作のインストラクションを調査者 15 名に示して, 各動作パターンへのインストラクシ ヨンが言語的動作特徵 13 グループに対してどの程度

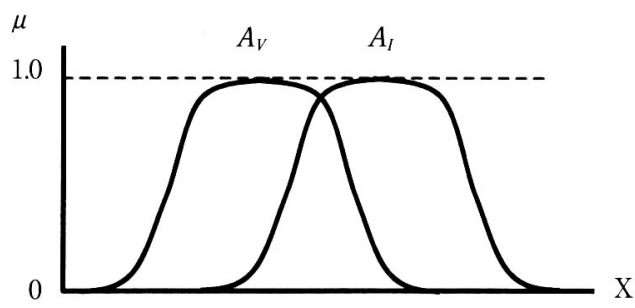

$A_{V}$ と $A_{I}$ の親近度

$$
P\left(A_{V}, A_{I}\right)=\frac{M\left(A_{V} \cap A_{I}\right)}{M\left(A_{V} \cup A_{l}\right)}
$$

$A_{V}$ の $A_{I}$ への被包含度

$$
R\left(A_{V}, A_{I}\right)=\frac{M\left(A_{V} \cap A_{I}\right)}{M\left(A_{V}\right)}
$$

$(M:$ ファジィ集合のカーディナリティ)

図 $11 \mathrm{X}$ 上の二つのファジィ集合間の親近度と被包含度 の導出

Fig. 11 Consistency and includedness between two fuzzy sets on $\mathrm{X}$-coordinate.

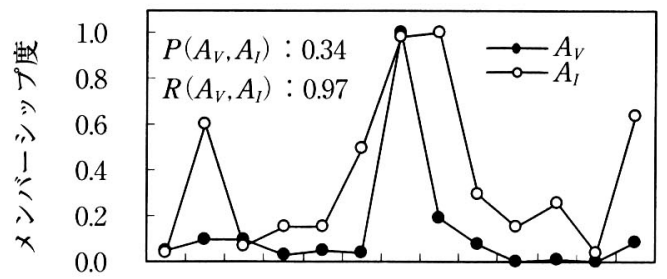

k1 k2 k3 k4 k5 k6 k7 k8 k9k10k11k12k13 動作パターン 1 : 䫟を引く

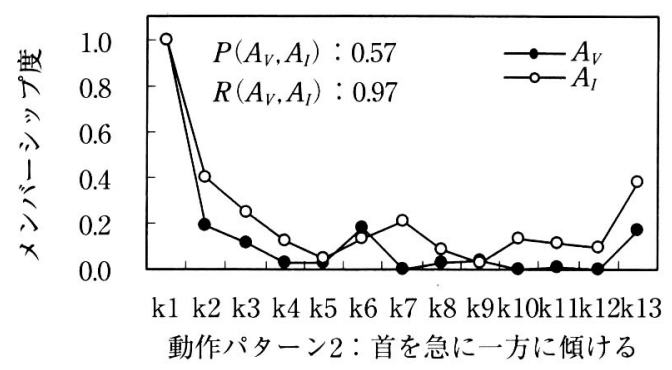

図 12 言語的動作特徴 13 グループに対するファジィ集合 $A_{V}$ と $A_{I}$ のメンバーシップ度の例

Fig. 12 Examples of membership ratio of fuzzy sets $A_{V}$ and $A_{I}$ about groups of linguistic motion features.

該当しているか記入してもらい，ファジィ集合 $A_{I}$ の メンバーシップ度とみなす。

（3）二つのファジィ集合 $A_{V}$ と $A_{I}$ の間の親近度 $P$ と被包含度 $R$ を算出する11,12) (図 11 参照).

図 12 に言語的動作特徵 13 グループに対するファジ 集合 $A_{V}$ と $A_{I}$ のメンバーシップ度の例を示す。図 


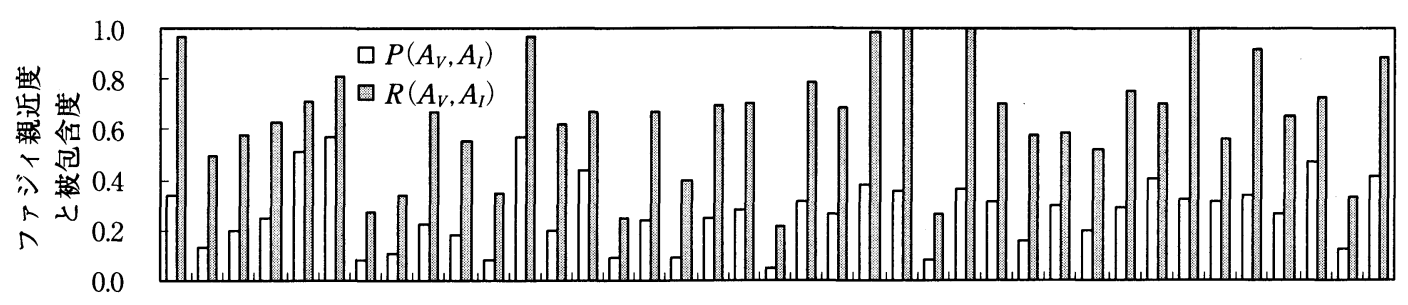

$122 \quad 3 \quad 4 \quad 5 \quad 6 \quad 7 \quad 8 \quad 9101112131415161718192021222324252627282930313233343536373839$ 動作パターン

図 13 各動作パターンに対するインストラクションの観察者の印象への親近度と被包含度

Fig. 13 Consistency and includedness between for every motion pattern.

13 に各動作パターンに対するインストラクションの 観察者の印象への親近度と被包含度を示す.

得られた $A_{V}$ と $A_{I}$ の間の親近度と被包含度は, 動 作パターンによって大きく值が異なった。まず $A_{V}$ と $A_{I}$ の間の親近度は, $0.04 \sim 0.57$ の值であり, 平均值 は 0.27 と低い值であった。これに対し $A_{V}$ の $A_{I}$ へ の被包含度は, $0.21 \sim 1.00$ の值であり, 39 動作パ夕 ーン中 30 動作パターンの值が 0.5 以上, 平均值は 0.65 と高い値であった。これらから, 演技者はイン ストラクションが与えられても, ひとつの動作パター ンしか行えないのに対して, インストラクションの調 查者は, インストラクションのもつ多表現性（一文の インストラクションが，いくつかの種類の動作パター ンで表現されうる）によって，多くの可能性を考えて いる.つまり現実に被験者によって表現された動作は インストラクションが表す動作の範囲に含まれている といえる。

\section{5. 結論および今後の課題}

本研究では, 身振りコミュニケーションに関して条 件の異なる二つの実験室下の動作計測実験を行い, 頭 部 5 箇所に貼り付けた光学マーカの位置データを三次 元動作解析装置によって測定し, そこから, 物理的動 作特徴を抽出し絞込み, それに基づいて, 言語的動作 特徵と人物の感情・意図の判別が行える可能性を示す ことができた。

膨大な量の測定点の時系列的な位置データから動作 モードを判別可能な指標を設定する意義は大きく，少 ない指標で, 高い判別率が得られれば, 測定点の数を 減らすことなどによって，データ量を減らすことがで きる. 現時点では, 動作の計測に三次元動作解析装置 を使用しているが, 将来的にインタフェースシステム を構築する上で, より安価な二次元/三次元動作解析 装置や，加速度計などの動作測定装置を適用する必要 が生じることから, 身体動作の部位および注目する物
理的動作特徴の指標の種類は重要な要素になってくる と考えられる. 今回判別に使用した物理的動作特徴の 指標のなかでも, 判別に大きく寄与しているものとそ うでないものがあった. 例えば, 眉間点の移動運動か ら算出された物理的動作特徵の指標の多くは, 判別に 大きく寄与していたが, これらに対して, 頭部の回転 運動から算出された物理的動作特徵の指標などは, 判 別にあまり寄与していなかった．抽出された物理的動 作特徵の指標は, 多変量解析手法によって機械的, ボ トムアップ的に設定されたものであるため，非言語表 現の動作モードによって, 動作の特徴, 様相を踏まえ た上で, 人間の主観をより反映させた物理的動作特徵 の指標を設定していくことが今後の課題であるといえ る.

実験者の意図と観察者の理解の一致性については, 実験では, 各インストラクションに対して 1 回の動作 パターンを演じてもらったため, インストラクション の持つ多表現性を被験者が十分には演技できなかった ものの, インストラクションに対応して期待される動 作パターンの範囲でなされていることが示唆された.

ところで，本来の自然なしぐさは実生活場面で自然 に表出されるものであり, 実験室下ではどうしても演 技特有の不自然さが生じてしまう。実験室下での実験 を実生活場面に近づけるよう工夫することは今後の課 題といえる. 今回の測定点は頭部 5 箇所であったが, 実際の自然なしぐさは頭部にとどまらず, 姿勢の変化 や，手などを併用した複合動作であるため, 数多くあ る非言語表現のなかでもごく一握りに注目したと言わ ざるを得ない. 判別に用いた動作モードも単純なもの がほとんどで, 複合的な動作には今回注目しなかっ た.今後複合的な動作に注目する場合, 動作の区切り 方や，文脈を考慮にいれた物理的動作特徵の指標を設 定していく必要がある.今回行った頭部の単純な動作 に関しては, 判別率等の值は高く, 以上の分析結果か ら, 構造モデル, 分析方法については, 限定的ではあ るが, 数理的アプローチの有効性が確認され, 非言語 
ヒューマンインタフェース技術への展開の可能性が示 唆されたといえる。

今後は, 本研究で構築する非言語インタフェースの 使用対象や，使用条件を設定したうえで，より効果的 な動作モードに注目していく．また，より高次の分析 を行うために, 多変量解析手法ではなくより柔軟に対 応できるニューラルネットワークやファジィ理論など の分析手法も取り入れていきたい.

\section{参考文献}

1）マジョリーF.ヴァーガス著, 石丸 正訳：非言 語コミュニケーション, 新潮選書, 東京, 1987.

2) $\mathrm{W}$ ・フォン・ラフラー=エンゲン編著, 本名信 行訳：ノンバーバル・コミュニケーション, 大修 館書店, 東京, 1981.

3）黒川隆夫：ノンバーバルインタフェース,オー ム社, 東京, 41〜 48, 1994.

4) Mark Billinghurst: Put That Where? Voice and Gesture at the Graphics Interface, Computer Graphics, 32(4), 60〜63, 1998.

5）久保宏一郎, 藤野雄一, 八木秀俊, 大塚作一：首
振り動作による障害者用文字入力システムの応 用, 電子情報通信学会技術研究報告, 99(10), 25～ $32,1999$.

6）ファジィ工学研究所：ファジィ思考による知的 情報処理, コンピュータ・エージ社, 東京, 251〜 267, 1995.

7）通商産業省工業技術院生命工学工業技術研究 所：設計のための人体計測マニュアル，日本出版 サービス, 東京, 4〜19, 1994.

8）小林祐子：しぐさの英語表現辞典，研究社，東 京, 1 681, 1991.

9）中谷和夫：多変量解析, 新曜社, 東京, 1978.

10）塩谷 寛：多変量解析概論，朝倉書店，東京， 1990.

11）中村和男：あいまいなカテゴリ反応データのフ アジィ構造分析，第 8 回ファジィシステムシンポ ジウム講演論文集, $641 〜 644,1992$.

12）中村和男：ファジィ理論と行動科学, ファジィ 理論と人文・社会科学（日本ファジィ学会編）, 189 240, 日刊工業新聞社, 東京, 1994. 